\title{
From Diplomacy to Contestation: Paradigm Shifts in the Zambia-China Relations, 1964-2011
}

\author{
Euston Kasongo Chiputa \\ Department of Historical and Archaeological Studies, School of Humanities and Social Sciences \\ University of Zambia, Lusaka, Zambia
}

\begin{abstract}
Between 1964 and 2011, relations between Zambia and China saw paradigm shifts from 'mutual' diplomatic relations to economic relations and eventually to contestation. China was an important pillar of the anti-colonial struggle in Zambia and the southern African sub-region. She provided economic and morale aid, logistical support, infrastructure building and education training for Zambia and other southern African countries. From 1964 until 1971, Zambia gave unflinching diplomatic support to China's cause for readmission to the United Nations. The 19642011 period saw the Zambia-China relationship undergo trio paradigm shifts; from China being an aid and loans provider to being an investor, from Chinese state-directed aid and loans to Chinese state and private investments in Zambia. From 2000, the Zambian people contested what they saw as Chinese invasion of their economic space. This paper explores these paradigm shifts in the Zambia-China relations between 1964 and 2011. The paper investigates whether China's relationship with Zambia gravitated from a benefactor-beneficiary relationship to 'mutual' benefit; punctuated by contestation by Zambians or whether the relations were tantamount to a Chinese "colonisation" of Zambia's economic landscape. Data for this paper was collected from official Zambian and Chinese government records and correspondence at the National Archives of Zambia. Other data was collected from the Archives of the United National Independence Party (UNIP) in Lusaka and from newspapers and secondary sources. These sources were subjected to comprehensive literature analysis to arrive at the conclusion that 1964 and 2011 the Zambia-China relations underwent three paradigm shifts from 'mutual' diplomatic relations to economic relations and eventually to contestation between.
\end{abstract}

Key Words: Paradigm shifts, Infrastructure, Contestation, Tazara, Zambia-China

\section{INTRODUCTION}

Scholarly discourse on Chinese presence in Zambia and Zambia-China relations has been on ascendancy with rapid pace, just as has been Chinese investments in Zambia. Ina Eirin Eliassen, Pentao Li, Dominik Kopinski and Andrzej Polus, as well as the Oxford Analytica separately see the ascendancy of the China-Zambia relations premised on historical diplomatic ties buoyed by Chinese aid and loans to Zambia, and Zambia's abundant natural resources and little expertise to harness them. ${ }^{1}$ China opened its first African

\footnotetext{
${ }^{1}$ Ina Eirin Eliassen, 'Chinese Investors: Saving the Zambian Textile and Clothing Industry?', Centre for Chinese Studies, Stellenbosch University, October, 2012, pp. 13, 46; Pentao Li, 'The Myth and Reality of Chinese Investors: A case study of Chinese Investment in Zambia's Copper Industry', Occasional paper No. 62, China in Africa Project, South African Institute of
}

embassy in Lusaka at Zambia's independence in 1964. China built the Tanzania-Zambia Railway (TAZARA) from the port of Dar Es Salaam in Tanzania to Kapiri Mposhi (commissioned in 1975) in Central province of Zambia. She built the Zambia-China Mulungushi Textiles factory (opened in 1981) in central Zambia and constructed various road infrastructure such as the Serenje-Samfya-Mansa and the Lusaka-Mongu roads. ${ }^{2}$ These relations reveal trio-paradigm shifts between 1964 and 2011. There was a gravitational shift from ideological considerations and Chinese aid and loans ${ }^{3}$ as the basis of China's relations with Zambia towards mutual economic relations on various economic fronts. Another shift was towards what some have called one sided neo-liberal Chinese economic gains more than ideological considerations. ${ }^{4}$ These shifts in turn engendered a third paradigm shift, contestations from citizens. This study combines archival and secondary sources to try and understand these paradigm shifts in the Zambia-China relations between 1964 and 2011.

Between 1964 and 1991, under the leadership of President Kenneth Kaunda, Zambia became an all-time friend of China. Following China's 1949 Communist Revolution and during the Cold War period (1947-1991) China saw Africa as a continent that needed to be wrested from the jaws of imperialism $^{5}$ in order to establish Chinese ideological presence. In welcoming Zambia's goodwill mission to Chinaled by Honourable Sikota Wina, Zambia's Minister of Information, Broadcasting and Tourism, the Chinese hosts at the airport shouted we 'resolutely support the Zambian

International Affairs, (May 2010), p. 3; Dominik Kopinski and Andrzej Polus, 'Sino-Zambian Relations: "An all-weather friendship" weathering the storm', Journal of Contemporary African Studies, Vol. 29, No. 2 (2011), p.181; 'Zambia-China relations will Survive Recent Violence', Oxford Analytica, (Tuesday, 21 August, 2012), p.1.

${ }^{2}$ NAZ/FA/1/64, Letter from MC Chona, Permanent Secretary, Ministry of Foreign Affairs to the Embassy of the People's Republic of China to Zambia, 8 November, 1966, and Letter from Permanent Secretary, Ministry of Foreign Affairs to Principal Private Secretary to His Excellency the President, 27 February, 1967; see also NAZ/FA/1/241, Letter from LM Lishomwa, Permanent Secretary, Ministry of Finance to MC Chona, Permanent Secretary, Ministry of Foreign Affairs, 1 June, 1967.

${ }^{3} \mathrm{NAZ} / \mathrm{FA} / 1 / 164$, Letter (translation) from Embassy of the People's Republic of China to the Ministry of Foreign Affairs, Lusaka, 13 February, 1967.

${ }^{4}$ Deborah Brautigam and Tang Xiaoyang, 'African Shenzhen: China's Special Economic Zones in Africa', The Journal of Modern African Studies, Vol. 49, No. 01 (March 2011), p. 28.

${ }^{5}$ NAZ/FA/1/94, 'Chinese Policy in Zambia', China Reconstructs, August, 1966. 
people's struggle against imperialism and colonialism and in defence of national independence'. ${ }^{6}$ This stemmed from the friction between China and the Western capitalist world led by USA, Britain, France, Italy, and Canada. The tone of this friction could also be gauged from President Kaunda's Telegram of $22^{\text {nd }}$ August, 1966 to Zambia's Ambassador to the United States of America, Samuel C. Mbilishi. The President directed Ambassador Mbilishi to reject the solicitation for support by honourable Robert Hamer Ridgewood, the Democratic candidate for the US Congress from New Jersey, against Vietnam and the admission of China to the United Nations. The response to Ridgewood on China was that China ' $\ldots$ is a world power which is likely to have great influence in world affairs which cannot be ignored.... ${ }^{7}$ Ridgewood was fearful that in no time China would replace western imperialism with its own brand, and it's influence and power over Zambia would amount to a Chinese 'colonisation'.

The first paradigm shift in the Zambia-China relations was from direct Chinese state aid and loans to a combination of Chinese state-owned enterprises and, private investments 'promoted and managed not by Chinese multinationals, but small and medium enterprises ... which sell low cost and lowvalue products of individual entrepreneurship'. ${ }^{9}$ China's rapid and successful emergence as an economic power house from the 1978 economic reforms, and China's non-attachment of stringent conditions to its economic aid packages, made Zambian leaders see China as an all-weather friend. ${ }^{10}$ Indeed, 'the Chinese ... emerged from under the radar to become ... some of the most powerful actors on the African continent'. ${ }^{11}$ Former British Prime Minister, Tony Blair, once stated that Chinese influence in Africa had grown from a 'standing start' to become the most influential foreign power in Africa. ${ }^{12}$ By 2007, according to Carmody and Taylor, Zambia had become Africa's third largest recipient (after South Africa and Sudan) of Chinese foreign direct investment (FDI) and nineteenth largest recipient in the world. ${ }^{13}$ Barry

${ }^{6}$ UNIP 7/25/13, 'Zambian Goodwill Mission Arrives in Peking', Nsinhua News Bulletin, 26 August, 1969.

${ }^{7}$ NAZ/FA/1/94, President Kaunda's Telegram to Mr. Samuel C. Mbilishi, Zambia's Ambassador to the United States of America, 22 August, 1966.

${ }^{8}$ Kalima Nkonde, 'How China slowly colonizing Zambian economy: Citizens wary of the dragon, Chinese President understands the fears',https://www.lusakatimes.com/2018/07/27/how-china-slowly-

colonizing-zambian-economy/, Accessed on Friday, 14 December, 2018.

${ }^{9}$ Chris Alden, 'Red Star, Black Gold', Review of African Political Economy,

Vol. 32, No. 104/105, Outlining the Wheels of Imperialism (June-Sept. 2005), p. 416.

${ }^{10}$ NAZ/FA/1/124, Trade Agreement between the Government of the Republic of Zambia and the Government of the People's Republic of China, 28 April, 1967.

${ }^{11}$ Padraig Carmody and Ian Taylor, 'Flexigemony and Force in China's GeoEconomic Strategy in Africa: Sudan and Zambia Compared', IIIS Discussion Paper No. 277, (January 2009), p.10.

12 Tony Blair, 'Faith and Globalisation', Cardinal Lecture at Westminster Cathedral, 3 April, 2018, published on 7 April, 2018, https://www.tonyblairoffice.org.2008/04/speech-on-faith-globalisation, Accessed on 7 April, 2018.

${ }^{13}$ Carmody and Taylor, 'Flexigemony and Force in China's Geo-Economic Strategy in Africa', pp.3, 4.; see also UNCTAD, 2007; Padraig Carmody and Godfrey Hampwaye, 'Inclusive or Exclusive Globalization? Zambia's
Sautman and Yan Hairong contend that China's establishment of special links with Africa arose from African countries' friendly migration policies and China's "Beijing Consensus" development model. ${ }^{14}$ China put great premium on its investments in Africa's generally little exploited natural resources and saw Zambia as a country lacking requisite finance, technology and expert human capital to develop its mineral, land and forest resources. China also literally "cashed" in on some African leaders' propensity for personal wealth accumulation and ambivalence to their countries' development agendas. By 2011, Chinese population in Zambia had reached $10,000 .{ }^{15}$ Meanwhile, the Zambian economy was going through challenges of high unemployment, a weaker local currency to the US dollar exchange rate, and generally foreign, especially Chinese exploitation of Zambian workers.

China's policies of "social modernisation" and market reforms announced by President Deng Xiaoping in December 1978 led to economic liberalisation and opened the country's economy to Foreign Direct Investment (FDI) through the establishment of "Special Economic Zones". Baah and Jauch say that because of China's consumption of $7.4 \%$ of world's oil, $31 \%$ of coal, $30 \%$ of iron ore, $27 \%$ of rolled steel, $25 \%$ of aluminium and $40 \%$ of the world's cement by 2004 , China overtook France and Britain to become a "global workshop" for production of toys, shoes, textiles and electrical appliances. This newly acquired economic prowess created an insatiable appetite for natural resources among China's emerging industries. They focused their specific interest on Africa's vast natural resources such as oil, copper, gold, diamonds, nickel, manganese and cobalt. Before the end of 2007 up to 7,000 Chinese enterprises had invested US118 billion in 173 countries, ${ }^{16}$ including Zambia. These Chinese successes indicate, as Dambisa Moyo shows, that the balance of economic power was rapidly shifting and China and India were overtaking the USA's world economic dominance. ${ }^{17}$ This made the Zambian political elite look to China mostly as a better economic alternative than the Western countries.

On the other hand, Africa's interest lay in China's financial aid, "cheap" loans and investment resources. Zambian

Economy and Asian Investment', Africa Today, Vol. 56, No. 3, Special Issue (2010), p. 86.

${ }_{14}$ Barry Sautman and Yan Hairong, 'Friends and Interests: China's Distinctive Links with Africa', African Studies Review, Vol. 50, No. 3 (Dec. 2007), p.75; see also Łukasz Fijałkowski, 'China's "soft power" in Africa?', Journal of Contemporary African Studies, Vol. 29, No. 2 (2011), Abstract.

${ }^{15}$ Hannah, Postel, 'Moving Beyond "China in Africa": Insights from Zambian Immigration Data', Journal of Current Chinese Affairs, Vol. 46, No. 2, (2017), p.155; see also Solange, Chatelard, 'No Place Like "Home": Exploring the "House" of the Chinese in Zambia', (2013). ASA 2013 Annual Meeting Paper, SSRN: https://ssrn.com/abstract=2237319, Accessed on Friday, 17 July 2020.

${ }^{16}$ Anthony Yaw Baah and Herbert Jauch, (eds.) Chinese Investments in Africa: A Labour Perspective, (Accra and Windhoek: African Labour Research Network, 2009), p. 3.

${ }^{17}$ Dambisa, Moyo, How the West was Lost: Fifty Years of Economic Folly and the Stark Choices Ahead, (London: Penguin Books, 2012), p.131. 
government leaders often, like other African leaders, paraded themselves before China to ask for aid and loans initially; and only later did some African leaders begin to stress investments rather than aid and loans. For China, the readily available natural resources, investment markets, conducive business climate and friendly people, particularly in Zambia, were irresistible. The Zambia-China bond was reinvigorated by assurances made at the 2006 Forum on China-Africa Cooperation (FOCAC) of Chinese and African leaders in Beijing. China's own policy of investing in Africa with 'no strings attached' gave further impetus to these initiatives. ${ }^{18}$ Moreover, $80 \%$ of China's loans were 'lowinterest, concessional finance from China's development banks such Export and Import Bank of China...., 19

The third paradigm shift rests on the view that Zambia's relations with China gravitated from mutual to tension, for example, on the labour and political fronts. China was accused of exerting economic dominance rather than promoting mutual benefit. The argument was that Chinese investors exploited their Zambian workers to the detriment of even the relations between China and Zambia, because the relations became anchored more on Chinese desire for exploitable resources for the Chinese rather than mutual benefit. But ordinary Zambians were not passive actors in these relations. They did not sit back and watch the Chinese arrive in Zambia and do as they pleased, uncontested. Zambians often reacted, in some cases violently, to register their indignation against Chinese 'invasion' of the Zambian economic space.

\section{Historical Background to Zambia-China Relations}

During the 1950s, China looked to independent African countries like Egypt, Ethiopia, the Gold Coast (Ghana), Liberia, Libya, and the Sudan for political and diplomatic links. ${ }^{20}$ Then, China did not have much international support, nor economic clout, having come through a communist revolution in 1949, which had ostracised her from the international, especially the Western capitalist world that had even expelled her from the United Nations. It was also a period overshadowed by the intense cold war following the end of the Second World War in 1945.

Specifically, China's relations with Zambia are traceable to the latter's independence in 1964. Zambia was the first African country to recognise the Chinese government by establishing diplomatic relations in that year, followed by

\footnotetext{
${ }^{18}$ Yan Hairong and Barry Sautman, "The Beginning of a World Empire"? Contesting the Discourse of Chinese Copper Mining in Zambia', Modern China, Vol. 39, No. 2 (March 2013), p. 132; NAZ/FA/1/124, Trade Agreement between Zambia and China, 28 April, 1967; Alden, 'Red Star, Black Gold', p. 418.

${ }^{19}$ Ferdinando, Cinotto, 'What Zambia's Debt Tells Us about the "China Debt Trap" Theory', https://www.thediplomat.com, Retrieved on Tuesday, 21 December, 2021.

${ }^{20}$ As quoted by Mohamed A. El-Khawas, 'China's Changing Policies in Africa', A Journal of Opinion, Vol. 3, No. 1 (Spring, 1973), p. 24; see also George McTurnan Kahin, The Asian-African Conference, Bandung, Indonesia, April, 1955 (Ithaca, New York: Cornell University, 1956), p.78.
}

trade relations, ${ }^{21}$ in spite of strong anti-communist sentiments across Western Europe and other capitalist capitals. Trade relations commenced with Zambia's commitment to export $1,100,000$ bags of maize to China, but due to lower yield than anticipated in that season, only 784,641 bags of maize were exported while 55,000 bags were at Beira Port in Mozambique in transit to China. ${ }^{22}$ Between 1974 and 1982, Zambia obtained large quantities of small arms from China for her National Service programme, in which Form Five secondary school leavers were trained in basic military and agricultural production skills. Youth military training was necessitated by the raging liberation and civil wars in five of Zambia's eight neighbouring countries. The resulting insecurity and instability threatened agricultural production and food security, requiring boosted agricultural production by state agencies like the Zambia National Service.

\section{Political Relations: Mutual Support}

When China demanded to re-join the United Nations in the late 1960s, Zambia spiritedly supported China's bid. On 27 November, 1967, Zambia's Permanent Representative to the United Nations, J.B. Mwemba, spoke in the General Assembly on 'Restoration of lawful rights of the People's Republic of China in the United Nations'. ${ }^{23}$ In a July 1968 letter from Zambia's Permanent Representative to the United Nations, Ambassador Vernon J. Mwaanga, to the Permanent Secretary, Ministry of Foreign Affairs, Lusaka, he stated that Zambia was one of the sixteen African countries that supported while nineteen African countries opposed, and two African countries abstained from China's readmission to the United Nations. ${ }^{24}$ When China finally reclaimed her seat at the United Nations in 1971, she remained cognisant of Zambia's unflinching support for that cause. In probable reciprocity, China accepted to build the Tanzania-Zambia Railway (TAZARA) line, a distance of 1,860 kilometres from Dar Es Salam port in Tanzania to Kapiri Mposhi in central Zambia, at

\footnotetext{
${ }^{21}$ NAZ/FA/1/94, Letter from Ho Ying, Representative of the People's Republic of China to President Kenneth D. Kaunda, Lusaka, requesting for immediate establishment of diplomatic relations between Zambia and China, October, 1966; 'Chinese Investments in Zambia', www.zda.org.zm/246chinese-investments-zambia, Accessed on Saturday, 14August, 2010.

$22 \mathrm{NAZ} / \mathrm{FA} / 1 / 241$, Correspondence between Permanent Secretaries of Ministries of Commerce and Industry, Ministry of Agriculture and Ministry of Foreign Affairs between 24 January, 1967 and 30 November, 1968.

${ }^{23}$ NAZ/FA/1/94, Statement made by H.E. Mr. J. B. Mwemba, Ambassador Extraordinary and Plenipotentiary Permanent Representative of the Republic of Zambia to the United Nations in the General Assembly on 'The Restoration of the Lawful Rights of the People's Republic of China in the United Nations', 2 November, 1967.

${ }^{24}$ NAZ/FA/1/94, Letter dated $23^{\text {rd }}$ January, 1968, from Permanent Secretary, Ministry of Foreign Affairs to Permanent Representative to the United Nations on the latter's statement in the United Nations General Assembly on 27 November, 1967; NAZ/1/94, 'Admission of the People's Republic of China to the United Nations', Letter from Vernon J. Mwaanga, Zambia's Permanent Representative to the United Nations to Permanent Secretary, Ministry of Foreign Affairs, Lusaka, 31 July, 1968. See also http://en.academic.ru/dic.nsf/enwiki/193400; Accessed on Friday, 14 December, 2018.
} 
a cost of US 500 million. ${ }^{25}$ The railroad was intended to give Zambia a lifeline, owing to the fact that in 1965 the rebel white minority regime in Rhodesia (Zimbabwe) hadmade a Unilateral Declaration of Independence (UDI). The immediate declaration of sanctions by the international community and Zambia, instigated by the United Kingdom, against the Rhodesian regime closed off Zambia's southern routes to the seaports in South Africa and Mozambique. Severe economic challenges were anticipated from 1966 onwards. ${ }^{26}$ Moreover, as Sikota Wina once put it while on a visit to Peking, China in 1969 'Zambia's efforts to develop the country had been greatly hampered by the racists in Mozambique, Rhodesia, South Africa and Angola' ${ }^{27}$ This made the construction of the TAZARA absolutely inevitable and.a great deal more urgent. In January 1969, the Times of Zambia newspaper reported that 'the 1,000-mile railway is planned as an alternative to Zambia's rail link to the coast through Rhodesia' ${ }^{28}$ The alternative Benguela Railway from Zambia's Copperbelt via Democratic Republic of Congo (DRC) to Lobito Bay in Angola faced grave difficulties due to, first the anti-colonial warfare in Angola up to 1975, and second, the civil war that broke out in DRC following independence in 1960. Another civil war broke out in Angola following the Portuguese pullout of that country in 1975. The Angolan civil war remained unresolved until 2002, when the main opponent of the ruling Popular Movement for the Liberation of Angola (MPLA) government, Jonas Savimbi of the Union for the Total Independence of Angola (UNITA) was shot dead by Angolan government forces near the Angola-Zambia border. Up to 2011, the Benguela Railway was not functional.

\section{Economic Relations: Aid and Loans}

Early in 1967, the Zambian and Chinese governments signed a trade agreement 'for the purpose of enhancing the friendship between the governments and peoples of Zambia and China and of developing the trade relations between the two countries on the basis of equality and mutual benefit .... ${ }^{29} \mathrm{Up}$ to the 1990s China's economic engagement with Zambia was by way of the Chinese state dealing directly with the Zambian government. The Chinese government undertook all Chinese trade, donor aid and loans to Zambia and other Sub-Sahara African countries. The Chinese state was the sole actor in China's international economic engagements. For example, in a letter (translation) dated 8 March, 1967, China's Embassy in Lusaka stated that:

\section{China has agreed to buy from Zambia the amount of one million $200 \mathrm{lb}$ bag maize and wishes to propose that China and Zambia hold talks on imports and}

\footnotetext{
${ }^{25}$ Dambisa Moyo, Dead Aid: Why Aid is not Working and How there is Another Way for Africa, (London: Penguin Books Ltd., 2010), p.103.

${ }^{26}$ NAZ/MF1/2/67, Bank of Zambia Annual Report, 1965, p. 9.

${ }^{27}$ UNIP 7/25/13, 'Zambian Goodwill Mission Arrives in Peking', Nsinhua News Bulletin, $26^{\text {th }}$ August, 1969, p.4.

28 'Early Start on Rail Link: Zambia-Tanzania Survey Months Ahead of Schedule', Times of Zambia, Saturday, 25 January, 1969.

${ }^{29}$ NAZ/FA/1/241, Trade Agreement between Zambia and China, 28 April, 1967.
}

exports simultaneously. But contracts will be signed separately and each side will pay cash in foreign exchange.

The Chinese government was very keen to strengthen the bilateral relations with Zambia as shown by their anxiety in this letter of 8 March, 1967. China wished to quickly emerge from the isolation imposed on her by the West, by aligning herself with, especially, African countries. China also wished to embark on economic transformation which needed massive natural resources, which she could acquire most easily only from Africa.

Beyond these trade initiatives, the Chinese government played a pivotal role in several China-Zambia infrastructure projects, through aid and outright loan packages. In a letter to his counter part in the Ministry of Agriculture, the Permanent Secretary of the Ministry of Commerce, Industry and Foreign Trade stated that 'in summing up (the meeting with Chinese Embassy officials), officials of the Ministry of Foreign Affairs also did emphasise Zambia's position with regard to the development of routes and our dependence on the Dar route'. ${ }^{31}$ This was in reference to the Zambian government's desire to open and improve trade routes alternative to the problematic southern routes. These talks formed the precursor to the establishment of the loan-funded TAZARA later in 1975, which became Zambia's biggest loan from China at the time. Chinese concessional loans became critical to Zambia's post-1964 infrastructure development trajectory. This was later buttressed by the Chinese President, Hu Jintao, who 'promised to double Chinese aid by 2009 and to provide US5 billion in preferential loans and export credits to Sub-Saharan Africa over 2006-2009, ${ }^{32}$

\section{Infrastructure Development: Roads and Railways}

\section{Roads}

Although the TAZARA is often hailed as the first sign of true friendship between China and Zambia, it was not the first infrastructure loan to be provided by the Chinese to Zambia. In 1966, during Vice President Reuben Chitandika Kamanga's visit to China, the Chinese government offered the Zambian government an interest free loan of up to Sterling $£ 6$ million, ${ }^{33}$ which, in 1967, Zambia wished to utilise to upgrade the

\footnotetext{
${ }^{30}$ NAZ/FA/1/241, Letter (translation) from Chinese Embassy, Lusaka to Ministry of Foreign Affairs of Zambia, 8 March, 1967; see also NAZ/1/FA/241, Telegram from Zambian High Commission in Dar Es Salaam to Ministry of Foreign Affairs, Lusaka, dated 26 May 1967, enquiring whether the 12,000 metric tons of maize would arrive at the port in June or July of that year for onward shipment to China.

${ }^{31}$ NAZ/FA/1//241, Letter from Permanent Secretary, Ministry of Commerce, Industry and Foreign Trade, to Permanent Secretary, Ministry of Agriculture, 12 June, 1967.

32 Ali Zafar, 'The growing Relationship between China and Sub-Sahara Africa: Macroeconomic, Trade, Investment, and Aid Links', www.jstor.org/stable, p. 125, Accessed on 26 August, 2015.

33 NAZ/FA/1/94, President Kenneth D. Kaunda's letter to the Right Honourable Chou En Lai, Prime Minister of the People's Republic of China, acknowledging the offer of the interest-free loan and the need to enhance trade relations, 15 February, 1967.
} 
Lusaka-Mongu Road. ${ }^{34}$ Later, the Chinese government agreed to help Zambia construct a critical road, linking Luapula Province in the north of Zambia to Central Province and the rest of the country. The road was intended to provide an alternative route to the Copperbelt-Luapula road that passes through the Congo pedicle; a landmass extending from southeastern Congo and jutting right into Zambia's central part, almost splitting the country into two. There were also security concerns caused by the civil war that had erupted in the Congo soon after that country's independence in 1960 followed by a Coup d'état in 1965. Zambian travellers were often harassed on the pedicle road, for all sorts of flimsy reasons including bald heads, protruding cheeks and buttocks, long hair and women wearing trousers! $!^{35}$ Zambians also spent nights on both sides of the Luapula River whenever they arrived after 18:00 Hours when the ferry on the river would have closed. This exposed Zambians to delays, and security risks on the Congo side of the border. The construction of the Tutaor 'Chinese ${ }^{36}$ Road, therefore, established a twenty-fourseven, safer and more reliable road link between Luapula Province and the rest of Zambia. This one-sided aid flow did not mean that China favoured Zambia; the Chinese were aware of Zambia's natural resource endowment which they hoped to tap into in future.

Although the Tuta was not completed until 1987, it was China's longest road project in Zambia. The road boasts one of Southern Africa's longest bridges, the Mukuku ${ }^{37}$ Bridge, which spans three and a half (3.5) kilometres across the Luapula River which forms the boundary between Central and Luapula provinces. Later, the Zambian government hired China Hennan, another Chinese company, to build the Mwanawasa Bridge at Chembe, to the west of the $3.5 \mathrm{~km}$-long Mukuku Bridge on the same river. In October 2008, Zambia's Acting President Rupiah Banda commissioned the bridge, replacing the pontoon ferry that had operated from the early colonial days. ${ }^{38}$

\footnotetext{
${ }^{34}$ NAZ/FA/1/64, Letter from MC Chona, Permanent Secretary, Ministry of Foreign Affairs to the Embassy of the People's Republic of China to Zambia, 8 November, 1966, and Letter from Permanent Secretary, Ministry of Foreign Affairs to Principal Private Secretary to His Excellency the President, 27 February, 1967; see also NAZ/FA/1/241, Letter from LM Lishomwa, Permanent Secretary, Ministry of Finance to MC Chona, Permanent Secretary, Ministry of Foreign Affairs, 1 June, 1967.

${ }^{35}$ This was attested by Zambian musician, Teddy Chilambe, in a song in Cibemba language about the harassment of Zambians travelling through the Congo pedicle road at the hands of Congolese border officials.

${ }^{36}$ The term Tuta means 'break the night' in Cibemba/Ushi languages, because unlike the Pedicle Road border which closed at 18:00 Hours every day, the Tuta road enabled people to travel throughout the night between Luapula Province and Central Province and on to other parts of Zambia. See also 'Road to Mweru Wantipa', www.zambia-travel-guide.com, Accessed Friday, 14 December, 2018.

${ }^{37}$ The term Mukuku means water/river current because the bridge is built across the Luapula River where the current was so strong the Chinese construction company had to divert the river into three separate streams to reduce the strong current of the river.

${ }^{38}$ 'RB Commissions Bridge', Zambia National Broadcasting Corporation (ZNBC), Saturday, 11 October, 2008; see also
}

\section{Railways}

The most ambitious infrastructure development project in which the Chinese aided Zambia was the construction of the Tanzania-Zambia Railway from the port of Dar Es Salaam in Tanzania to Kapiri Mposhi in central Zambia, where it linked up with the Zambia Railways line. The TAZARA took five years (1970-1975) to build a total of 1,860 kilometres and cost a staggering US 500 million, making it the largest foreign project ever undertaken by China then. This was an interestfree loan from the Chinese people to the peoples of Zambia and Tanzania. The TAZARA and Zambia Railways together transported 85 per cent of Zambia's imports and 90 per cent of the country's exports. ${ }^{39}$ The TAZARA opened a new communication corridor through East Africa to the rest of the world, an alternative to the beleaguered traditional southern rail route. In all these relationships, the Chinese knew that there would come a time when they would require Zambia to reciprocate their 'aid gestures' through, what later came to be, investment incentives.

China invested US 500 Million to build TAZARA for a number of reasons. China wished to put on record that her technological advancement had come of age, capable of competing with Western technological developments, and actually surpassing them. Initially the Zambian government of Kenneth Kaunda had approached some Western European countries for the TAZARA project. All had declined, citing the project as a non-starter given the expansive and undulating nature of the terrain to be covered by the railway line. Thus, the Chinese ably constructed the railway line which Western countries had declined to do.

However, after several years of neglect, the two railway systems fell into almost total collapse. Meanwhile, the booming mining industry on the old Copper belt and the "new Copperbelt' of North-Western provinces needed a stable and reliable transport infrastructure, which the two railway systems could no longer fully provide. Recourse was to the road infrastructure, Given Zambia's land-linked nature and geo-political environment, a heavy burden was placed on the country's road infrastructure causing massive determination. TAZARA's performance faced various challenges. Eight years after the railway line had commenced operation, the Chinese expressed displeasure in the manner it was being run, and attributed most problems to Zambia, for keeping the wagons too long in Zambia and failing to collect freight charges. They also felt that the railway was being '....underutilised because Zambia prefers to use the southern routes for most of its imports and exports' ${ }^{40}$ The southern route had since reopened following the independence of

https://www.lusakatimes.com/2008/10/12/rb-commissions-bridge/,Sunday, 12 October, 2008, Accessed on 10 March, 2013.

39 Republic of Zambia, National Commission for Development Planning (NCDP), Fourth National Development Plan, 1989-93, Vols. I and II, Chapter XVI,p. 236.

${ }^{40}$ UNIP 7/25/96, Report on Sino-Zambian Relations by J. Shonga, Charge D' Affaires, Zambian Embassy in Peking, $7^{\text {th }}$ June, 1983. 
Zimbabwe in April 1980. TAZARA continually needed cash injections to keep it afloat, and up to 2011, China had been bailing the TAZARA out of financial handicaps through concessional loans. One of such was an interest-free loan of US39 million in 2010 to revive TAZARA operations. ${ }^{41}$

\section{Cooperation in Agriculture and Manufacturing}

Other areas of the China-Zambia state-to-state cooperation from 1964 were in the fields of agricultural development and manufacturing. As stated earlier, agricultural cooperation had started in 1968 with the Chinese importation of $1,100,000$ bags of maize from Zambia, though not all were delivered due to limited supply in Zambia. ${ }^{42}$ Despite such challenges, '...Chinese support to Zambia's agricultural development... ${ }^{43}$ remained significant. In fact , a significant portion of China's FDI in Zambia went to agriculture and construction, with about US10,032,866, thereby creating 1,093 jobs, while Johnken Friendship Farm and China Harvest Investment Limited invested US1,840,000 and US1,800,000 respectively. ${ }^{44} \mathrm{Apart}$ from these farms, there were other private Chinese people who invested in agriculture to the extent that Chinese investment outlay in agriculture in Zambia was only second to mining.

Prior to 1991, a significant portion of Zambia's manufacturing industry had been a preserve of the state. The industries had either been acquired through nationalisation or built via national development plans from 1964 to 1971, through the import substitution industrialisation (ISI) strategy. Most were financed by profits from the mining industry which the state also used as a subsidy pipeline for the rest of the state-owned manufacturing companies. ${ }^{45}$ The earliest significant industry of a manufacturing nature that the Chinese attempted in Zambia on a state-to-state basis was the Zambia-China Mulungushi Textiles in Kabwe. The Textiles began as a vibrant Zambian state-run cloth manufacturing factory both for local consumption and export. Working as a near monopoly, competing only with Kafue Textiles, and the privately owned Mukuba Textiles and Swarp Spinning Mills both in Ndola, the Mulungushi Textiles appeared insulated from stiff competition in cloth production. However, the arrival of the liberalised economic regime from 1991brought fierce competition from already-made products, ironically

\footnotetext{
41 'Zambia: ZCTU Salutes China for Bailing Out Tazara', Times of Zambia, Wednesday, 13 January, 2010.

42 NAZ/FA/1/241, Correspondence between Permanent Secretaries of Ministries of Commerce and Industry, Ministry of Agriculture and Ministry of Foreign Affairs, 1968.

${ }^{43}$ Hairong, Yan and Sautman, Barry, 'Chinese Farms in Zambia: From Socialist to "Agro-Imperialist" Engagement? African and Asian Studies, Volume 9, Number 3, (2010), see Abstract.

${ }^{44}$ Austin C Muneku, 'Chinese Investments in Zambia', in Baah and Jauch (eds.) Chinese Investments in Africa: A Labour Perspective, p. 174.

${ }^{45}$ Ina Eirin, Eliassen, 'Chinese Investors: Saving the Zambian Textile and Clothing Industry?', p.12; Freek Cronje, Suzzanne Reyneke and Charity Chenga, 'Corporate Social Responsibility in the Zambian Mining Sector: An Overview of three distinctive operational levels', ttps://www.researchgate.net/publication/319045925, p.7, Accessed on Wednesday, 13 February, 2019.
}

from China! The Mulungushi Textiles shrank and eventually folded up as competition from Chinese finished products intensified and killed off the Mulungushi spirit of manufacturing.

\section{Human Capital Development}

From the very time of the Communist Revolution in 1949, the Chinese Communist Party (CCP), aided by the Confucian philosophy of meritocracy, frugality, education and individual sacrifice, saw investments particularly in higher education as crucial ingredients in national skills development. By the time Chairman Mao (the esteemed founder of the Chinese Communist state) died in 1976, China had built up various education, training and research institutions intended to upscale that country's human capital capacity. When the Chinese government liberalised the country's economic landscape, China already possessed more than enough of the required critical mass of trained and skilled labour resource. In the post-1978 period China's economy witnessed an upswing, a result of the earlier calibrated investments in education development through expansion and modernisation.

China extended a hand of friendship to Zambia in human capital development from very early in their relationship. In 1966 Zambia and China signed agreements with regard to manpower training opportunities for Zambians in China. In a 1966 Agreement on Cultural Cooperation between Zambia and China, Article 2 stated that 'the two contracting parties shall accept students of the other party according to their respective systems governing studies' ${ }^{46}$ Zambian students often went to China for training in fields such as medicine, agriculture, education, engineering, military and others. In 2010 some Chinese students and scholars were doing research in Zambian public universities, just as Zambians were doing the same in China. By 2011, there were more than one hundred Zambian students studying in various Chinese universities and colleges through the China-Zambia bilateral cooperation, while others were studying privately there. China's comparative advantage in the education, science and technology sectors and in research and development $(\mathrm{R} \& \mathrm{D})$ was mostly due to the foresight of that country's leaders.

\section{The Paradigm Shifts}

In the 1990s China's relations with Zambia andthe rest of Africa underwent two major paradigm shifts. Firstly, the Chinese state policy changed from China merely giving aid and loans to actually investing in Zambia and other African countries, though loans continued on softer conditions than those obtaining on the international market. In 2006 David Seddon wrote that although Chinese investment in Africa still lagged behind USA's and Britain's, 'within five years... China could be one of the top three investors in the

\footnotetext{
${ }^{46} \mathrm{NAZ} / \mathrm{FA} / 1 / 155$, Article 2, Agreement on Cultural Cooperation between the Government of the Republic of Zambia and the Government of the People's Republic of China, $22^{\text {nd }}$ August, 1966.
} 
continent' ${ }^{47}$ True to Seddon's prediction, by 2011 China had become the major investor in Africa. Back in China too, economic policy shifts were steadily building momentum. The Chinese private sector was being given more business space to operate.

Secondly, the Chinese government changed from being the major player in its external economic relations. Chinese stateowned enterprises and some private firms took the front row. Particularly, the failure of Western aid, loans and foreign direct investment (FDI) to impact positively on the African people's lives through poverty reduction, made Africa look especially to China, for solutions. Also, because aid from Western countries based on criteria determined largely by the same Western governments was not yielding the desired results, most Sub-Saharan African countries looked to China to boost and remodel their economic trajectories. Thus, Chinese companies set up base in Zambia to engage in mining, manufacturing, agriculture, trade and commerce, as well as construction, quarrying and brick making. They set up operations even in sectors and places generally shunned by traditional western and other investors. In 2008 five per cent of the 570,000 cubic meters of copper output in Zambia was produced by Chinese mining firms,${ }^{48}$ such as China NonFerrous Metals Corporation that had acquired the Luanshya Mine (twice abandoned by two different previous investors). On $5^{\text {th }}$ August, 2009, the Jinchuan Group announced that it was to acquire 51 per cent shares in the Australian-owned Albidon Nickel Mine in Mazabuka in southern Zambia, which had closed in March 2009 due to low nickel prices, partly occasioned by the 2008 global recession. ${ }^{49}$ Thus, in spite of the contestation from both Zambian and foreign entities, the Chinese continued to invest in Zambia.

Other reasons can be advanced for these paradigm shifts. The Chinese government embarked on its own brand of liberalisation of the economic space, opening up to both local and foreign private investors. This rapidly transformed the Chinese economy and business environment. Thes earch for raw materials put Chinese firms on a maritime silk road to Africa to find these much-needed resources, which offered four key advantages. Firstly, the resources were readily available; secondly, they were cheap, and thirdly the labour required to harness these resources was also relatively cheap in Africa in general and Zambia in particular. In the fourth place was the ambivalent reaction of African politicians to the exploitation of their countries' resources by foreign firms, and China took full advantage of this.

\footnotetext{
${ }^{47}$ David Seddon, 'China: Africa's new Business Partner', Review of African Political Economy, Vol. 33, No. 110, Religion, Ideology and Conflict in Africa (Sept. 2006) p. 747.

${ }^{48}$ Zambia Development Agency (ZDA), 'Chinese Investment in Zambia', www.zda.org.zm/246-chinese-investments-zambia, Accessed on 14 Saturday, August, 2010.

${ }_{49}$ Zambia Development Agency (ZDA), 'Chinese Investment in Zambia, 2010.
}

Zambia's liberalisation and democratisation processes that had taken effect from 1991 made the private sector key actors in the country's economic drive, and opened the country to Foreign Direct Investment (FDI). Difficulties associated with Africa's disagreements with the European Union (EU) on the Economic Partnership Agreements (EPAS) since the beginning of the twenty-first century added strength to the pro-China African responses to foreign economic overtures.

Before 1991, Zambia's mining landscape had been dominated by the state, with the mines having been nationalised back in the 1969-70 period through the Mulungushi and Matero Reforms, which were praised then as '... absolutely necessary if independence is to be meaningful to the people of Zambia ${ }^{50}$ This was reversed in 1991 with the liberalisation of the Zambian economy which in turn enabled Chinese firms to make very significant inroads into Zambia's extractive and other industries. The Zambia Development Agency (ZDA), a state agency tasked to coordinate investments in Zambia, according to Claude Kabemba, recorded that 166 Chinese firms invested US\$ 666 Million and created over 11,000 jobs. ${ }^{51}$ As at 2011, the biggest Chinese investments in Zambia were in mining, with China Non-Ferrous Metals Corporation leading the pack. It was the biggest and earliest Chinese mining company to arrive in Zambia, and by 2011 the company owned two major mines, Chambishi and Luanshya mines. By 2011 the Chinese had become increasingly involved in every facet of the Zambian economy.

\section{Mutual Benefit or Chinese colonisation: To what Extent?}

While saying all these things, questions to do with what benefits and for whom and to what extent need to be asked. Early in 1967, the Times of Zambia newspaper reported Mr Cecil Burney, Independent MP for Ndola as stating in Parliament that Zambia's Grain Marketing Board's maize export to China was not beneficial to Zambia because the whole deal was at a loss! Although the Minister of Commerce, Industry and Foreign Trade, Mr Justin Chimba, refutedMr Burney's argument in Parliament, he was unable to provide counter statistics. ${ }^{52}$ The Zambia-China relations remained relatively calm until much later in the 2000s, when China began to look to Africa more intensely for natural resources. For example, in 2005, in an article titled 'Red Star, Black Gold', Chris Alden wrote that although:

Once an avowedly anti-imperialist force on the continent with aspirations to third world leadership, Beijing's recent foray into Africa has been characterised by a singular focus on resource

\footnotetext{
${ }^{50}$ UNIP 7/25/13, Excerpt from Sikota Wina's speech during Zambia's Goodwill Mission meeting in Peking', China, Nsinhua News Bulletin, 26 August, 1969, p.4.

${ }_{51}$ Claude Kabemba, 'Chinese Involvement in Zambia', http://www.osisa.org/books/zambia/chinese-involvementzambia.html,,Accessed Friday, 14 December, 2018.

52 ‘ $£ 1.2 \mathrm{~m}$. may be lost on deal’, Times of Zambia, Thursday, 13 July, 1967.
} 
acquisition and commercial opportunism that seemingly belies the rhetoric of partnership. ${ }^{53}$

This resonates well with the various dissenting voices against Chinese investors in Zambia, just as Sata's 2006 and 2011 anti-Chinese dominance election campaign sentiments are corroborated by Baah and Jauch who state that 'in Zambia, for example, the Chinese copper mine paid its workers $30 \%$ less than other copper mines in the country'. ${ }^{54}$ The Chinese companies also had a propensity to recruit from China both skilled and unskilled personnel at the expense of local Zambian labour; and they offered poorer working conditions and salaries, safety and health standards than the firms they found in Zambia. ${ }^{55}$ For example, during the early phase of the Chambishi Multi-Facility Economic Zone (MFEZ) construction, there were 400 Chinese workers against 500 Zambian workers; yet 'early in the construction phase, the Ethiopian Oriental Industrial Park had about thirty Chinese staff with shifting numbers of local workers ${ }^{56}$ The Ethiopian case demonstrates that it was possible to use the Chinese on local projects without giving them any leeway to dominate the local space.

To gauge whether the Zambia-China relations were mutual, it is important to analyse some of the contentious points and investments in Zambia. Often, Chinese firms were accused of bringing their own nationals to do unskilled jobs which Zambians could do, Chinese employers using racist and abusive language to their Zambian employees, and Chinese firms not providing their workers with protective clothing, and blatantly flouting Zambian labour laws. Baah and Jauch state that in general Chinese companies do not grant African workers any meaningful benefits and in some instances ignore even those that are prescribed by law' ${ }^{57}$ Chinese mining firms were given various tax incentives and such protective legal instruments as the:

\section{Investment guarantees and protection against state nationalization through the Certificate of Registration....under the Zambia Development Act 2006; Guarantees through Zambia's participation in the World Bank Group's Multilateral Investment Guarantee Agency; and (Zambia's) Member(ship) of the International Convention on the Settlement of Investment Disputes. ${ }^{58}$}

In addition to these incentives and guarantees, in 2009 the Zambian government through Minister of Finance, Situmbeko

\footnotetext{
${ }^{53}$ Alden, 'Red Star, Black Gold', p. 415.

${ }^{54}$ Baah and Jauch (eds.) Chinese Investments in Africa, See Executive Summary, p.13.

${ }^{55}$ Dan Hugland, 'In It for the Long Term? Governance and Learning among Chinese Investors in Zambia's Copper Sector', The China Quarterly, No. 199, (September, 2009), p.629.

${ }^{56}$ Deborah Brautigam and Tang Xiaoyang, 'African Shenzhen: China's Special Economic Zones in Africa', p.44.

${ }_{58}^{57}$ Baah and Jauch (eds.) Chinese Investments in Africa, p. 13.

58 Republic of Zambia, Zambia Development Agency, http://www.zda.org.zm/?q=content/investment-guarantees, Accessed on Thursday, 31 January, 2019.
}

Musokotwane, withdrew the 2007 Windfall Tax (paid on profits that exceed certain limits due to sudden increases in commodity prices). ${ }^{59} \mathrm{He}$ argued that windfall tax would paralyse the mines by scaring away investors!

Further, the failure of the country's growing Chinese economic influence to rescue the majority of the Zambian poor from the jaws of excruciating poverty created its own problems. The Chinese were and continued to be accused of taking all the Zambian government, and even private sector, infrastructure contracts. They were also accused of engaging in petty businesses which, ordinarily, were supposed to be the preserve of indigenous Zambians. Some people accused Chinese contractors of even bringing Chinese labourers to their projects in Zambia. This denied semi-skilled and unskilled Zambians vital employment opportunities. Both local and foreign opponents of Chinese presence in Zambia continually contested their presence and investments ${ }^{60}$ and accused the Zambian government of harbouring a 'soft heart' for the Chinese; that Zambian leaders were indigenising the Chinese to the detriment of Zambians. They argued that China was 'slowly taking over or "colonising" Zambia', ${ }^{61}$ given that the Chinese loans to Zambia were too much for Zambia to repay. Some even argued that it was unnecessary for Zambia and other Sub-Saharan countries to contract the kinds of debt they were getting from China. James Bovard and Dambisa Moyo separately support this view by arguing that foreign aid did not bring any significant change that respective countries could not achieve on their own, but merely heightened poverty and engendered economic ruin. ${ }^{62}$

In 2006, Chinese firms almost halted their spike of investments in Zambia, fearing nationalisation once popular opposition Patriotic Front (PF) party leader Michael Sata assumed the reins of power. Alastair Fraser states that Sata 'successfully mobilized popular sentiments by vehemently criticizing Chinese companies, promising to expel foreign investors who abused their workforce, and threatening diplomatic confrontation with ... ${ }^{63}$ (China). Michael Sata felt that Zambians deserved better treatment and investments than the Chinese were offering. He insisted that Chinese

\footnotetext{
59 Sangwani Patrick Ng'ambi, 'Stabilisation Clauses and the Zambian Windfall Tax', www.researchgate.net. Accessed Friday, 14 December, 2018.

${ }^{60}$ George Schoneveld, Laura German and Davison Gumbo, 'The developmental implications of Sino-African economic and political relations: A preliminary assessment for the case of Zambia', Working paper No. 133, Centre for International Forestry Research, 2014, p. 1.

61'Zambia: Under Chinese influence', France 24, https://www.france24.com/en/tv-shows/reporters/20210705-zambia-underchinese-influence-full-length-version, Accessed Sunday, 28 November, 2021. ${ }^{62}$ James Bovard, 'The Continuing Failure of Foreign Aid', CATO Institute, CATO Policy Analysis, No. 65, p. 1; see also Dambisa Moyo, Dead Aid: Why Aid is not Working and How there is another Way for Africa, (London: penguin Books, 2010), pp. 46-47.

${ }^{63}$ Alastair Fraser, 'Introduction: Boom and Bust on the Zambian Copperbelt', in Alastair Fraser and Miles Larmer, Zambia, Mining, and Neoliberalism: Boom and Bust on the Globalized Copperbelt (New York: Palgrave Macmillan, 2010), p.18.
} 
investments and emerging economic dominance ${ }^{64}$ in Zambia were not adding much value to the Zambian economy because of the low wages paid to Zambian workers, inferior Chinese goods in Chinese wholesale and retail shops, particularly in the Chinese reconstructed Luburma (Kamwala) Market shopping complex, in Lusaka's second class trading area. On 6 September 2006 The Post newspaper carried a story that 'Chinese firms have suspended investments in Zambia's copper mines and will cut diplomatic ties with the African country (Zambia) if the main opposition leader Michael Sata wins the September 28 (2006) presidential elections.... ${ }^{65}$ Michael Sata did not win the elections, nor did the Chinese halt their investments in Zambia. Some private Chinese firmsevenopened and engaged in mining of particularly manganese in Central, Northern and Luapula provinces of Zambia. This sometimes resulted in some Chinese people ending up on the wrong side of the law.

The treatment of Chinese nationals caught on the wrong side of the law was a major cause of disagreement too. It was argued that such Chinese nationals had been left to go scotfree for far too long. In 2008 a Chinese couple caught with stolen copper cathodes hidden in their house in the Copperbelt town of Kitwe was released without charge, which raised great consternation in the nation. Many Zambians felt that Zambia could not hope to have mutual benefit from an investment climate skewed in favour of foreign investors like Chinese firms. Others, especially government leaders, counter-argued that these were just the first pangs of child birth; once such industries settled down, immense benefits would begin to accrue to the Zambian people. Such sentiments in turn gave credence to the counter-view that Chinese investments, and the presence of so many Chinese people in Zambia, was the new super highway to the Chinese takeover or colonisation of Zambia.

Although Michael Sata did not win the 2006 elections, his views are very important because they lead to asking other questions. For example, were the Chinese investors merely replacing the imperialist, capitalist investors of old from the Western world? If so, what mutual benefits would accrue to Zambia if no benefits had accrued earlier in the old Africanimperialist relationships? Yan and Barry assert that exploitation of farm workers lies at the core of agro-capitalist production, and the Chinese could easily adopt it if their leaders in Beijing dictated so. ${ }^{66} \mathrm{~A}$ relationship is only mutual when the partners agree on it and the benefits are mutually shared. This did appear to be so in the Zambia-China relationship, because the mutual agreements signed on the political altar did not translate into tangible mutual benefits for the ordinary Zambian people.

\footnotetext{
${ }^{64}$ Kristin Palitza, 'Why Zambia's Elections Will Be All About China', Time Magazine, 19 September, 2011.

${ }^{65}$ 'China may suspend its Investments in Zambia', The Post, Wednesday, 6 September 2006.

${ }^{66}$ Yan and Barry, 'Chinese Farms in Zambia: From Socialist to "AgroImperialist" Engagement?', see Abstract.
}

\section{The Pitfalls of the Investments}

To systematically analyse the pitfalls of the Chinese investments in Zambia, it would be worthwhile stating that the modalities of Chinese investments in Zambia were not different from elsewhere in the world where the Chinese had established investment portfolios. In a paper published in the Review of African Political Economy, Aleksandra Gadzala argued that Chinese-owned Chambishi Mine was bringing so many Chinese workers into Zambia, thereby crowding ordinary Zambians out of formal employment. ${ }^{67}$ From this scenario and, as stated earlier, during Michael Sata's campaign speeches, the opponents of Chinese investments in Zambia were vindicated. The case of the appalling working conditions at the Chinese-owned Collum Coal Mine in Maamba, Southern Province, where coal miners without protective clothing crawled into and out of coal tunnels was another subject of contestation. Southern Province Minister Mrs Alice Simango, 'in 2006 ... openly wept after seeing miners emerge semi-naked and barefoot from the tunnel ${ }^{68}$ of the coal mine.

Several arguments can be raised from the Collum Coal Mine story above. The first is that it is not worthy having people work for a firm merely to enrich the firm owners at the workers' expense. This was especially the Zambian labour unions' point of view. They insisted on paying a living wage, that should enable the earner to afford a satisfactory livelihood. Meanwhile, the government needed the tax money that the investors paid to it. So, the government was bound to turn a blind eye to the exploitation of its own citizens by international capital, in the name of facilitatingFDI. The leaders believed that Zambia's benefits lay in the long term; because in an economy that was just picking up, paying high wages would cripple such ventures. The result would be to close them and send the employees onto the streets. Such leaders did not realise that investors in mining, for example, were mining a wasting resource. Mining would eventually cease, leaving Zambia with nothing but a collection of pits and underground tunnels, and having enriched foreigners at the expense of their own citizens. Speaking at a Workshop on 'Chinese Aid and Investment in Zambia', on 17 March 2009, Chairman of Zambia's Private Sector Development Association, Yusuf Dodia echoed Dambisa Moyo's view that aid does not change anything but merely 'distorts the development process.... ${ }^{69}$ Using China's 2006 commitment of US7 trillion to Sub-Sahara Africa's infrastructure development which was three times more than the region's

\footnotetext{
${ }^{67}$ Aleksandra, W. Gadzala, 'From formal- to informal-sector employment: examining the Chinese presence in Zambia', Review of African Political Economy, Vol. 37, No. 123 (March 2010), pp.41-42.

${ }^{68}$ 'Collum coal mine given licence back, set to open', lusakatimes.com, Accessed on Friday, 3 April, 2015.

${ }^{69}$ 'Chinese Aid and Investment in Zambia', National Consultation Workshop, A Report, organised by Africa Forum Aid Networking on Debt and development (AFRODAD), Civil Society Trade Network of Zambia (CSTNZ), Jesuit Centre for Theological Reflection (JCTR) and Civil Society for Poverty reduction (CSPR), Courtyard Hotel, Lusaka, (17 March, 2009), p.7.
} 
traditional World Bank support, Dodia further agreed with Dambisa Moyo, to show that even the above increase in Chinese aid to Sub-Saharan Africa would not necessarily translate into development, because China's own rapid economic transformation was not premised on aid. ${ }^{70}$

\section{Prospects for the Future}

Although prospects for the Zambia-China relations looked bright, whether prospects for Zambia's benefits from these relations were also bright was another matter. Zambia's prospects could only be as bright as the Zambian political leaders determined. Zambia's benefits from the investments on her land could be even brighter if the benefits accruing from such investments were equitably shared through better wages for Zambian workers, and better taxes for the state. Although there was contestation against Chinese firms from various sections of the Zambian public and political forces, it would be unlikely for anyone to undo the highly cemented relationship between China and Zambia.

While it could not be said that the relationship was cast in stone, the roots of the Zambia-China relationship had sunk very deep over the years, uprooting them would be a monumental task of either outright expropriation or lengthy legal battles. Moreover, back in 1969, the Zambian government had stated that:

\begin{abstract}
Many countries have looked upon our acceptance of aid from China (the railway and the road) as a sinister step towards Eastern political infiltration into Zambia .... It is important to remember, too, that there are no strings attached to this Chinese aid' ${ }^{, 71}$
\end{abstract}

By 2010, the political rhetoric of expelling Chinese investors had died down, but during the 2011 national election campaigns, the anti-China rhetoric was resuscitated. However, Chinese firms proved to be the main, the most serious and the heaviest risk takers of the latest investors in Zambia's mining and other economic sectors. ${ }^{72}$ Chinese investments in mining in Zambia turned out to be the most diversified, the fastest growing and the most adventurous in terms of taking on even the most financially risky undertakings. This included buying of abandoned mines. Upon assuming power in 2011, without explanation, President Michael Sata abruptly abandoned his anti-Chinese stance. This just showed the extent of Chinese entrenchment in the Zambian economic space.

Therefore, one would want to believe that prospects for the China-Zambia relations were bright and were yet to blossom further, but prospects for Zambia's benefits from such foreign investments were certainly not as bright.

To sum up the prospects for the Zambia-China relations from 1964 to 2011, the views in 2010 of Buleti Nsemukila, then
Permanent Secretary in Zambia's Ministry of Commerce, Trade and Industry were valid, that:

China's involvement in many development programmes including mining, energy, road construction and the development of multi-facility economic zones is intended to expand the economy further. Zambia should brace for more investment from China....Last year (2009) government signed an Investment Protection Agreement with one Chinese firm that has committed to invest more than USD 5 billion. $^{73}$

Nsemukila's views were in accord with Sangwani Ng'ambi's statement that:

The concession agreement between the government of Zambia and the mining companies contained Stabilisation Clauses which constitute a promise on the part of the host government not to amend its laws in a way that adversely affects the economic rights contained within that particular concession agreement. ${ }^{74}$

Given such safeguards, undoing the investment agreements could only happen at a nation's peril. President Sata must have come face to face with this stark reality, hence his change of rhetoric against the Chinese on becoming President in 2011. On the other hand, keeping investment agreements that were one-sided and meant to benefit the investors at the expense of the owners of the resources was equally at a nation's peril.

\section{CONCLUSION}

This paper concludes that between 1964 and 2011 the Zambia-China relations witnessed three major paradigm shifts. The first two shifts in turn engendered a third paradigm shift, contestation from citizens who saw Chinese investments as scandalously exploitative and demeaning to Zambians.

Chinese state-owned and private firms rather than the Chinese state itself, became the key actors in the various fields of the China-Zambia relationship particularly after 1991. Chinese private firms and individuals could be found in various sectors of the Zambian economy. They invested in mining, manufacturing (especially in steel recycling), quarrying, brick

\footnotetext{
${ }^{73}$ http://www.zambianwatchdog.com/2010/02/09/chinese-investment-inzambia, Accessed on $9^{\text {th }}$ February, 2010.

${ }^{74}$ Sangwani Patrick Ng'ambi, 'Stabilisation Clauses and the Zambian Windfall Tax', www.researchgate.net. Accessed

Friday, 14 December, 2018.
}

\footnotetext{
70 'Chinese Aid and Investment in Zambia', National Consultation Workshop, A Report, p.7.

71 'Early Start on Rail Link', Times of Zambia, Saturday, 25 January, 1969.

${ }^{72}$ Baah and Jauch (eds.) Chinese Investments in Africa, p.24.
} 
making, wholesale and retail trading, running restaurants, bakery, fuel retail pump stations, agriculture and agroprocessing including aquaculture. Zambians contested that most of these ventures were supposed to be preserves of citizens rather than foreigners (the Chinese).

However, although by 2011 the Zambia-China relations had gravitated from a one-sided affair of Chinese aid and loans to Zambia, to include investments, the scenario was punctuated by contestation against perceived Chinese dominance and exploitation of Zambia's human and natural resources. The contestations showed that the relationship was clearly onesided, to the extent that the argument that China was out to take over and colonise Zambia's economy held sufficient credence. Clearly, between 1964 and 2011, in spite of the contestations, the Zambia-China relationship was skewed in favour of China rather than Zambia.

\section{REFERENCES}

[1] ' $£ 1.2 \mathrm{~m}$. may be lost on deal', Times of Zambia, Thursday, $13^{\text {th }}$ July, 1967.

[2] Abraham, Curtis, 'China's long History in Africa', NewAfrican magazine, 11 March 2015.

[3] Alden, Chris, 'Red Star, Black Gold', Review of African Political Economy, Vol. 32, No. 104/105, Outlining the Wheels of Imperialism (June-Sept. 2005), pp. 415-419.

[4] Baah, Yaw, Anthony and Jauch, Herbert (eds.) Chinese Investments in Africa: A Labour Perspective, Accra and Windhoek: African Labour Research Network, 2009.

[5] Blair, Tony, 'Faith and Globalisation', Cardinal Lecture at Westminster Cathedral, $3^{\text {rd }}$ April, 2018, published on $7^{\text {th }}$ April, 2018, https://www.tonyblairoffice.org.2008/04/speech-on-faithglobalisation, Accessed on $7^{\text {th }}$ April, 2018.

[6] Bovard, James, 'The Continuing Failure of Foreign Aid', CATO Institute, CATO Policy Analysis, No. 65, 31 January 1986.

[7] Brautigam, Deborah and Xiaoyang, Tang, 'African Shenzhen: China's Special Economic Zones in Africa', The Journal of Modern African Studies, Vol. 49, No. 01, (March 2011), pp. 2754.

[8] Carmody, Padraig and Hampwaye, Godfrey, 'Inclusive and Exclusive Globalisation? Zambia's Economy and Asian Investment', Africa Today, Vol. 56, No. 3, Special Issue (2010), pp. 84-102.

[9] Carmody, Padraig and Taylor, Ian, 'Flexigemony and Force in China's Geo-Economic Strategy in Africa: Sudan and Zambia Compared', IIIS Discussion Paper No. 277, January 2009.

[10] Chatelard, Solange, 'No Place Like 'Home': Exploring the 'House' of the Chinese in Zambia', (2013). ASA 2013 Annual Meeting Paper, SSRN: https://ssrn.com/abstract=2237319, Accessed on Friday, 17 July 2020.

[11] 'China may suspend its Investments in Zambia', The Post, Wednesday, 6 September 2006.

[12] Cinotto, Ferdinando, 'What Zambia's Debt Tells Us about the "China Debt Trap" Theory', https://www.thediplomat.com, Accessed on Tuesday, 21 December, 2021.

[13] 'Early Start on Rail Link: Zambia-Tanzania Survey Months Ahead of Schedule', Times of Zambia, Saturday, 25 January, 1969.

[14] Eliassen, Ina Eirin, 'Chinese Investors: Saving the Zambian Textile and Clothing Industry?', Centre for Chinese Studies, Stellenbosch University, October, 2012.

[15] El-Khawas, Mohamed A. 'China's Changing Policies in Africa', A Journal of Opinion, Vol. 3, No. 1 (Spring, 1973), pp. 24-28.

[16] Fijałkowski, Łukasz, 'China's "soft power" in Africa?', Journal of Contemporary African Studies, Vol. 29, No. 2 (5 April, 2011), pp. 223-232.

[17] Fraser, Alastair, 'Introduction: Boom and Bust on the Zambian Copperbelt', in Fraser, Alastair and Larmer,Miles (eds.), Zambia,
Mining, and Neoliberalism: Boom and Bust on the Globalized Copperbelt, New York: Palgrave Macmillan, 2010, pp.2-30.

[18] Gadzala, Aleksandra, W., 'Sino-African Relations during the Tang Dynasty (618-907 A.D.)', http://aleksandragadzala.blogspot.com/, Accessed on Wednesday, 30 January, 2013.

[19] Gadzala, Aleksandra W., 'On the Chinese Presence in Zambia, from formal- to informal-sector employment: examining the Chinese presence in Zambia', Review of African Political Economy, Vol. 37, No. 123 (March 2010), pp. 41-59.

[20] Hairong, Yan and Sautman, Barry, "The Beginning of a World Empire"? Contesting the Discourse of Chinese Copper Mining in Zambia', Modern China, Vol. 39, No. 2 (March 2013), pp. 131164.

[21] Hairong, Yan and Sautman, Barry, 'Chinese Farms in Zambia: From Socialist to "Agro-Imperialist" Engagement?', African and Asian Studies, Volume 9, (1 January, 2010), pp. 307-333.

[22] https://www.lusakatimes.com/2018/07/27/how-china-slowlycolonizing-zambian-economy/, Accessed on Friday, 14 December, 2018.

[23] Hugland, Dan, 'In It for the Long Term? Governance and Learning among Chinese Investors in Zambia's Copper Sector', The China Quarterly, No. 199, (September, 2009), pp. 627-646.

[24] Jeffrey,Andrew, 'LookingBack ontheLine', www.news.bbc.co.uk/1/hi/africa/4020069,stm, Accessed on Wednesday, 17 November, 2004.

[25] Kabemba, Claude, "Chinese Involvement in Zambia', http://www.osisa.org/books/zambia/chinese-involvementzambia.html,, Accessed on Friday, 14 ${ }^{\text {th }}$ December, 2018.

[26] Kahin, George McTurnan, The Asian-African Conference, Bandung, Indonesia, April, 1955, Ithaca, New York: Cornell University, 1955.

[27] Kopinski, Dominik and Polus, Andrzej, 'Sino-Zambian Relations: "An all-weather friendship" weathering the storm', Journal of Contemporary African Studies, Vol. 29, No. 2 (2011), pp. 181192.

[28] Li, Pentao, 'The Myth and Reality of Chinese Investors: A case study of Chinese Investment in Zambia's Copper Industry', Occasional paper No. 62, China in Africa Project, South African Institute of International Affairs, May, 2010.

[29] Martin, Anthony, Minding Their Own Business: Zambia's Struggle against Western Control, London: Hutchinson and Co. Ltd., 1972.

[30] Mourdoukoutas, Panos 'What Is China Doing in Africa?' Forbes, https://www.forbes.com/sites/panosmourdoukoutas/2018/0 8/04/china-is-treating-africa-the-same-way-european-colonistsdid/\#78ae8220298b, Accessed on Wednesday, 13 February, 2019.

[31] Moyo, Dambisa, How the West was Lost: Fifty Years of Economic Folly - and the Stark Choices Ahead, London: Penguin Books, 2012.

[32] Muneku, C. Austin, 'Chinese Investments in Zambia', in Baah and Jauch (eds.) Chinese Investments in Africa: A Labour Perspective, (Accra and Windhoek: African Labour Research Network, 2009), pp. 160-202.

[33] NAZ/FA/1/94, 'Admission of the People's Republic of China to the United Nations', Letter from Vernon J. Mwaanga, Zambia's Permanent Representative to the United Nations to Permanent Secretary, Ministry of Foreign Affairs, Lusaka, 31 July, 1968.

[34] NAZ/ FA/ 1/ /241, Letter from Permanent Secretary, Ministry of Commerce, Industry and Foreign Trade, to Permanent Secretary, Ministry of Agriculture, 12 June, 1967.

[35] NAZ/ FA/ 1/ /241, Telegram from Zambian High Commission in Dar Es Salaam to Ministry of Foreign Affairs, Lusaka, dated 26 May 1967.

[36] NAZ/ FA /1/ /241, Trade Agreement between the Government of the Republic of Zambia and the Government of the People's Republic of China, 28 April, 1967.

[37] NAZ/FA/1/155, Agreement on Cultural Cooperation between the Government of the Republic of Zambia and the Government of the People's Republic of China, 22 August, 1966. 
[38] NAZ/FA/1/241, Letter from LM Lishomwa, Permanent Secretary, Ministry of Finance to MC Chona, Permanent Secretary, Ministry of Foreign Affairs, 1 June, 1967.

[39] NAZ/FA/1/241, Correspondence between Permanent Secretaries of Ministries of Commerce and Industry, Ministry of Agriculture and Ministry of Foreign Affairs between 24 January, 1967 and 30 November, 1968.

[40] NAZ/FA/1/64, Letter from MC Chona, Permanent Secretary, Ministry of Foreign Affairs to the Embassy of the People's Republic of China to Zambia, 8 November, 1966, and Letter from Permanent Secretary, Ministry of Foreign Affairs to Principal Private Secretary to His Excellency the President, 27 February, 1967.

[41] NAZ/FA/1/94, 'Chinese Policy in Zambia', China Reconstructs, August, 1966.

[42] NAZ/FA/1/94, Letter dated 23 January, 1968, from Permanent Secretary, Ministry of Foreign Affairs to Permanent Representative to the United Nations on the latter's statement in the United Nations General Assembly on 27 November, 1967.

[43] NAZ/FA/1/94, Letter from Ho Ying, Representative of the People's Republic of China to President Kenneth D. Kaunda, Lusaka, requesting for immediate establishment of diplomatic relations between Zambia and China, October, 1964.

[44] NAZ/FA/1/94, President Kaunda's Telegram to. Samuel C. Mbilishi, Zambia's Ambassador to the United States of America, 22 August, 1966.

[45] NAZ/FA/1/94, President Kenneth D. Kaunda's letter to the Right Honourable Chou En Lai, Prime Minister of the People's Republic of China, acknowledging the offer of the interest-free loan and the need to enhance trade relations, 15 February, 1967.

[46] NAZ/FA/1/94, Statement made by H.E. Mr. J. B. Mwemba, Ambassador Extraordinary and Plenipotentiary Permanent Representative of the Republic of Zambia to the United Nations in the General Assembly on 'The Restoration of the Lawful Rights of the People's Republic of China in the United Nations', 27 November, 1967.

[47] NAZ/FA/1/ 164, Letter (translation) from Embassy of the People's Republic of China to the Ministry of Foreign Affairs, Lusaka, 13 February, 1967.

[48] NAZ/MF1/2/67, Bank of Zambia Annual Report, 1965.

[49] Ng'ambi, Sangwani Patrick, 'Stabilisation Clauses and the Zambian Windfall Tax', www.researchgate.net. Accessed on Friday, 14 December, 2018.

[50] Nkonde, Kalima, 'How China slowly colonizing Zambian economy: Citizens wary of the dragon, Chinese President understands the fears', https://www.lusakatimes.com/2018/07/27/how-china-slowlycolonizing-zambian-economy/, Accessed on Friday, 1December, 2018 .
[51] Palitza, Kristin, 'Why Zambia's Elections Will Be All About China', Time Magazine, 19 September, 2011.

[52] Postel, Hannah, 'Moving Beyond "China in Africa": Insights from Zambian Immigration Data', Journal of Current Chinese Affairs, Vol. 46, No. 2, (2017), pp. 155-174.

[53] Republic of Zambia, National Assembly, Debates of the First Session of the Second National Assembly, 21 June - 23 April 1969, Budget Address by Minister of Finance, Simon Mwansa Kapwepwe (30 June 1969) p. 135.

[54] Republic of Zambia, National Commission for Development Planning (NCDP) Fourth National Development Plan, 1989-93, Lusaka: NCDP, 1988.

[55] 'Road to Mweru Wantipa', www.zambia-travel-guide.com, Accessed on Friday, 14 December, 2018.

[56] Sautman, Barry, and Hairong, Yan, 'Friends and Interests: China's Distinctive Links with Africa', African Studies Review, Vol. 50, No. 3 (Dec. 2007), pp. 75-114.

[57] Schoneveld, George, German, Laura and Gumbo, Davison, 'The developmental implications of Sino-African economic and political relations: A preliminary assessment for the case of Zambia', Working paper No. 133, Centre for International Forestry Research, 2014.

[58] Seddon, David, 'China: Africa's New Business Partner', Review of African Political Economy, Vol. 33, No. 110, 'Religion, Ideology \& Conflict in Africa', (Sep., 2006), pp. 747-749.

[59] 'TAZARA

Railway', http://en.wikipedia.org/wiki/TAZARA_Railway, Accessed on Friday, 13 August 2010.

[60] UNIP 7/25/13, 'Zambian Goodwill Mission Arrives in Peking', Nsinhua News Bulletin, 26 August, 1969.

[61] UNIP 7/25/13, Excerpt from Honourable Sikota Wina's speech during Zambia's Goodwill Mission meeting in Peking', China, Nsinhua News Bulletin, 26 August, 1969.

[62] UNIP 7/25/96, Report on Sino-Zambian Relations by J. Shonga, Charge D' Affaires, Zambian Embassy in Peking, 7 June, 1983.

[63] Zafar, Ali, 'The growing Relationship between China and SubSahara Africa: Macroeconomic, Trade, Investment, and Aid Links', www.jstor.org/stable, p. 125, Accessed on 26 August, 2015.

[64] Zambia Development Agency (ZDA), 'Chinese Investment in Zambia', www.zda.org.zm/246-chinese-investments-zambia, Accessed on Saturday, 14 August, 2010.

[65] 'Zambia: ZCTU Salutes China for Bailing Out Tazara', Times of Zambia, Wednesday, 13 January, 2010.

[66] 'Zambia-China Relations Will Survive Recent Violence', Oxford Analytica, (Tuesday, 21 August, 2012), p. 3.

[67] 'Zambia: Under Chinese influence', France 24, https://www.france24.com/en/tv-shows/reporters/20210705zambia-under-chinese-influence-full-length-version, Accessed Sunday, 28 November, 2021. 